MINERALOGIA, 42, No 1: 39-51 (2011)

DOI: 10.2478/v10002-011-0005-8

www.Mineralogia.pl

MineRALOGICAL Society of Poland

Polskie TOWARZYSTWO MINERALOgICZNE

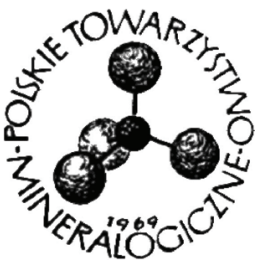

Original paper

\title{
Trace element geochemistry of coals from the Southern Cantabrian Zone (NW Spain): preliminary results
}

\author{
Dariusz BOTOR ${ }^{1}$ \\ ${ }^{1}$ Faculty of Geology, Geophysics and Environmental Protection, AGH Univeristy of Science and Technology \\ al.Mickiewicza 30,30-059 Kraków, Poland;e-mail:botor@agh.edu.pl
}

Received: October 30, 2010

Received in revised form: August 18, 2011

Accepted: March 10, 2012

Available online: March 28, 2012

\begin{abstract}
Bituminous to anthracite coals from three small Stephanian intramontane coal-bearing basins (La Magdalena, Cinera-Matallana and Sabero) located along the Sabero-Gordón fault line strike-slip systems of the Southern Cantabrian Zone (SCZ) were examined. Coal rank expressed as mean vitrinite reflectance values of these Stephanian coals is in the range $0.72-3.96 \%$. The vitrinite maceral group exceeds $72 \mathrm{vol}$. \% in all of the coals. The coals are characterized by relatively variable contents of mineral matter and coal-ash. The mineral matter comprises, in the main, clay minerals, carbonates, sulphides and quartz. The coals exhibit medium-high concentrations (see for comparison Ronov et al. 1990; Kabata-Pendias, Pendias 1999; Ketris, Yudovich 2009) of the following elements (in ppm): $\mathrm{REEE}$ (53-205), Ba (300-900), As (11-57), Zn (<50-150), Cr (10-160), Rb (50145), Co (5-26), Sc (2-24.6), Ce (17-99), Yb (1.3-4.5), Th (2.4-11.9) and U (1.1-8.1), Br (<1-14), Cs (<2-9), Eu $(<0,3-1.5), \mathrm{Lu}(0.11-0.85)$ and $\mathrm{Sb}(0.8-4.8)$, and relatively low concentrations of $\mathrm{Sm}(0.6-6.6)$ and $\mathrm{Ta}(<1-2)$. They are also characterised by relatively high $\mathrm{Th} / \mathrm{U}$ values (1.31-2.29). LREE/HREE values fall in the range 24-44 (average - 30). In contrast, concentrations of $\mathrm{Au}, \mathrm{Ag}, \mathrm{Hg}, \mathrm{Ir}, \mathrm{Ni}, \mathrm{Se}, \mathrm{Sn}, \mathrm{Sr}$, and $\mathrm{W}$ are below detection limits for the applied INAA method. As the concentrations of elements are significantly higher in coal-ash, most are likely related to mineral matter in the coals.
\end{abstract}

Key-words: trace elements, coal, Cantabrian Mountains, Spain

\section{Introduction}

Trace elements occurring in coals contribute in a significant way to environmental pollution due to the large amounts of coal combusted (e.g. Querol et al. 1996). Generally, 
eighty-six elements have been detected in coals and, among them, 24 trace elements are of environmental concern (Swaine 1995). The environmental impact of trace elements is related to concentration, toxicity, and mobility (modes of occurrence) of these elements in coals (e.g. Finkelman 1995). The elemental abundances in coals are related to coalaccumulating peat-swamp environments, geological processes during deposition and postdeposition, and bedrock properties (e.g. Cohen et al. 1984, Finkelman 1995). The major minerals in coals are silicates, carbonates and sulphates. Most elements are concentrated in these minerals. However, $\mathrm{Ge}, \mathrm{B}, \mathrm{Br}, \mathrm{Be}$ and $\mathrm{Cl}$ are usually associated with the organic matter (Finkelman 1995; Swaine 1995). In this paper, the term "bituminous coal" is used according to standard ISO 7404-5 (1994) and ISO 11760 (2004).

Most of the Spanish coal basins are located in the Cantabrian Mountains. They contain $70 \%$ of the total coal resources of Spain, including $95 \%$ of the anthracitic- and bituminous resources (e.g. Colmenero, Prado 1993; Colmenero et al. 2008; Frings et al. 2004). Despite this, few studies have been performed on their origin and quality. The purpose of this study was to investigate the distribution of trace elements in selected Stephanian coals and to identify the major factors that influenced the geochemistry of these coals.

\section{Geological setting}

The Cantabrian Zone represents the foreland belt of the Variscan Iberian Massif (Marcos, Pulgar 1982). It consists of Precambrian basement covered by Paleozoic sediments. These experienced intense thin-skinned tectonics, diagenetic- to epizonal thermal events and several episodes of fluid flow in Carboniferous-Permian times (e.g. Pérez-Estaún et al. 1988; Bastida et al. 1999; Brime et al. 2001; Aller et al. 2005). All of the three coal-bearing basins examined are small intramontane structures located along the Sabero-Gordón the strike-slip fault line systems of the Southern Cantabrian Zone (SCZ, Fig. 1). Stephanian coal-bearing clastic sequences $(<2500 \mathrm{~m}$ thick) rest uncomfortably on the older rocks and were likely deposited in a pull-apart basin (e.g. Heward 1978; Heward,
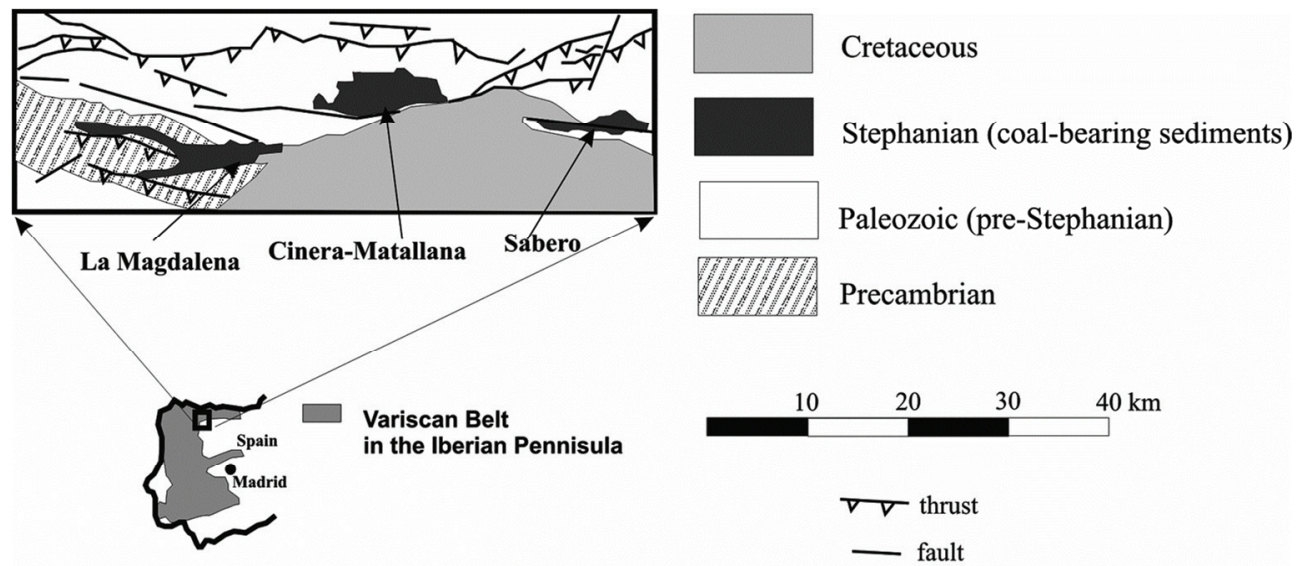

Fig. 1. Simplified geological sketch-map showing the location of the study coalfields in the Southern Cantabrain Zone (NW Spain) (Bastida et al 1999; Colmonero et al. 2008 modified by the author). 
Reading 1980; Knight 1983; Knight et al. 2000; Colmenero et al. 2008). The post-Variscan history was characterized by a long period of non-deposition and erosion before Cretaceous sedimentation $(<800 \mathrm{~m})$ occurred in the area (e.g. Bastida et al. 1999).

\section{Samples and methods}

Nine Stephanian coal samples were collected at a depth of $0.5 \mathrm{~m}$ from outcrops in the following coalfields: La Magdalena (M15), Cinera-Matallana (CM6) and Sabero (1s, 4s, 5s, $11 \mathrm{~s}, 16 \mathrm{~s}, 27 \mathrm{~s}, 41 \mathrm{~s})$. More detailed data on coal petrology of a much wider sample set and the local geological setting are given elsewhere (Botor 2009). Petrologic analyses were carried out in reflected, white light. Analytical procedures used in microscopic studies followed International Committee for Coal and Organic Petrology (ICCP) standards (International Organization for Standardization 1994; 2004). Random reflectance measurements $(\% \mathrm{Rr})$ of collotelinite were carried out on polished grain sections using an Axioskop-Opton microscope in non-polarized reflected white light mode using a (50x) oil immersion objective (refractive index $\mathrm{n}=1.5176$ at $\mathrm{T}=23{ }^{\circ} \mathrm{C}$ ). The results were interpreted using a computerized system. Macerals were identified for 500 points using a semi-automatic point counter. The ash and sulphur contents were determined according to the Polish standards (Polski Komitet Normalizacyjny 2001, 2002). Over thirty elements in coals were analysed the INAA method. The sampled coals were crushed and pulverized to obtain homogenous samples suitable for whole-rock analysis. The INAA analyses were performed by Activation Laboratories, Ltd. (Canada). Additionally, some samples were investigated on the Cameca SX100 electron microprobe (Faculty of Geology, Warsaw University) using an accelerating voltage of $15 \mathrm{KV}$ and beam current of $29 \mathrm{nA}$, with a $20 \mathrm{~mm}$ defocused electron beam (Dzierżanowski 2009, personal communication).

\section{Results and discussion}

The Stephanian coals in the SCZ are, in general, vitrinite-rich coals (moderately high vitrinite - high vitrinite coals according to PN-ISO 11760 (Polski Komitet Normalizacyjny 2007). They contain variable percentages of inertinite and limited or no liptinite maceral content, particularly in the case of high-rank coals (Table 1). These observations are in agreement with the results of previous studies (Colmenero et al. 2008; Frings et al. 2004; Colmenero, Prado 1993). The vitrinite maceral group predominates in all of the samples with contents varying from 72-90 vol.\%, while inertinite group macerals vary from 4 14.6 vol.\% (Table 1). The Stephanian coals of the SCZ are composed mainly of collodetrinite and collotelinite occurring with inertodetrinite and semifusinite, and, less commonly, macerals of fusinite and funginite (Table 1). Mean random vitrinite reflectance values for the analysed SCZ coals fall in the range $0.72-3.96 \%$ though most values are between $1.01-1.53 \%$ (Table 2 ). 
TABLE 1

Maceral composition of the Stephanian coals analyzed Stephanian coals from the Southern Cantabrian Zone.

\begin{tabular}{|c|c|c|c|c|c|c|c|c|c|c|}
\hline \multirow[t]{2}{*}{ Sample } & \multicolumn{4}{|c|}{ Macerals } & \multicolumn{6}{|c|}{ Group } \\
\hline & cd. & ct. & fung. & fus. & semifus. & inertod. & V & I & $\mathrm{L}$ & M \\
\hline $11 \mathrm{~s}$ & 37.4 & 47.5 & 0.2 & 0.7 & 2.0 & 3.1 & 84.9 & 6.0 & 0 & 9.1 \\
\hline $16 \mathrm{~s}$ & 51.5 & 20.5 & 0.3 & 0.8 & 4.0 & 4.0 & 72.0 & 9.1 & 0 & 18.9 \\
\hline $1 \mathrm{~s}$ & 49.0 & 34.1 & 0.2 & 1.2 & 1.1 & 9.0 & 83.1 & 11.5 & 0 & 5.4 \\
\hline $27 \mathrm{~s}$ & 62.0 & 19.5 & 0.9 & 1.0 & 3.2 & 9.3 & 81.5 & 14.4 & 0 & 4.1 \\
\hline $41 \mathrm{~s}$ & 71.0 & 19.0 & 0.0 & 0.2 & 0.9 & 6.0 & 90.0 & 7.1 & 0 & 2.9 \\
\hline $4 s$ & 57.4 & 19.6 & 0.0 & 1.4 & 1.1 & 1.5 & 77.0 & 4.0 & 0 & 19.0 \\
\hline $5 s$ & 46.5 & 19.3 & 0.2 & 1.8 & 3.0 & 9.6 & 65.8 & 14.6 & 0 & 19.6 \\
\hline M15 & 52.5 & 24.0 & 0.4 & 3.1 & 3.0 & 8.0 & 76.5 & 14.5 & 0 & 9.0 \\
\hline CM6 & 57.1 & 25.3 & 0.0 & 1.1 & 1.2 & 4.0 & 82.4 & 6.3 & 0 & 11.3 \\
\hline \multicolumn{11}{|l|}{ Note: } \\
\hline V & \multirow{5}{*}{\multicolumn{3}{|c|}{$\begin{array}{l}\text { vitrinite group } \\
\text { inertinite group } \\
\text { liptinite group } \\
\text { mineral matter }\end{array}$}} & cd. & \multicolumn{6}{|c|}{ collodetrinite } \\
\hline I & & & & ct. & \multicolumn{6}{|c|}{ collotelinite } \\
\hline $\mathrm{L}$ & & & & fung. & \multicolumn{6}{|c|}{ funginite } \\
\hline M & & & & fus. & \multirow{2}{*}{\multicolumn{6}{|c|}{ fusinite }} \\
\hline & & & & semifus. & & & & & & $\begin{array}{l}\text { semifusinite } \\
\text { inertodetrinite }\end{array}$ \\
\hline
\end{tabular}

TABLE 2

Ash and sulphur content and vitrinite reflectance of analyzed Stephanian coals from Southern Cantabrian Zone.

\begin{tabular}{|c|c|c|c|c|}
\hline Sample & $\begin{array}{l}\text { Coal ash } \mathrm{A}^{\mathrm{d}} \\
\% \text { wt. }\end{array}$ & $\begin{array}{l}\text { Sulphur total } \mathrm{S}_{\mathrm{t}}^{\mathrm{d}} \\
\% \text { wt. }\end{array}$ & $\begin{array}{l}\text { Vitrinite reflectance } \mathrm{Rr} \\
(\%)\end{array}$ & Standard deviation of $\mathrm{Rr}$ \\
\hline $11 \mathrm{~s}$ & 17.76 & 0.79 & 1.35 & 0.04 \\
\hline $16 \mathrm{~s}$ & 42.00 & 0.71 & 1.15 & 0.07 \\
\hline $1 \mathrm{~s}$ & 24.10 & 0.17 & 1.31 & 0.04 \\
\hline $27 \mathrm{~s}$ & 7.75 & 0.61 & 3.96 & 0.10 \\
\hline $41 \mathrm{~s}$ & 24.00 & 1.26 & 1.26 & 0.07 \\
\hline $4 \mathrm{~s}$ & 39.59 & 0.35 & 1.13 & 0.11 \\
\hline $5 \mathrm{~s}$ & 31.07 & 0.75 & 1.53 & 0.09 \\
\hline M15 & 7.01 & 0.71 & 1.01 & 0.05 \\
\hline CM6 & 24.50 & 1.05 & 0.72 & 0.05 \\
\hline
\end{tabular}

NOTE: $\mathrm{d}$ - dry basis, $\mathrm{t}$ - total, $\mathrm{Rr}$ - random vitrinite reflecatnce 


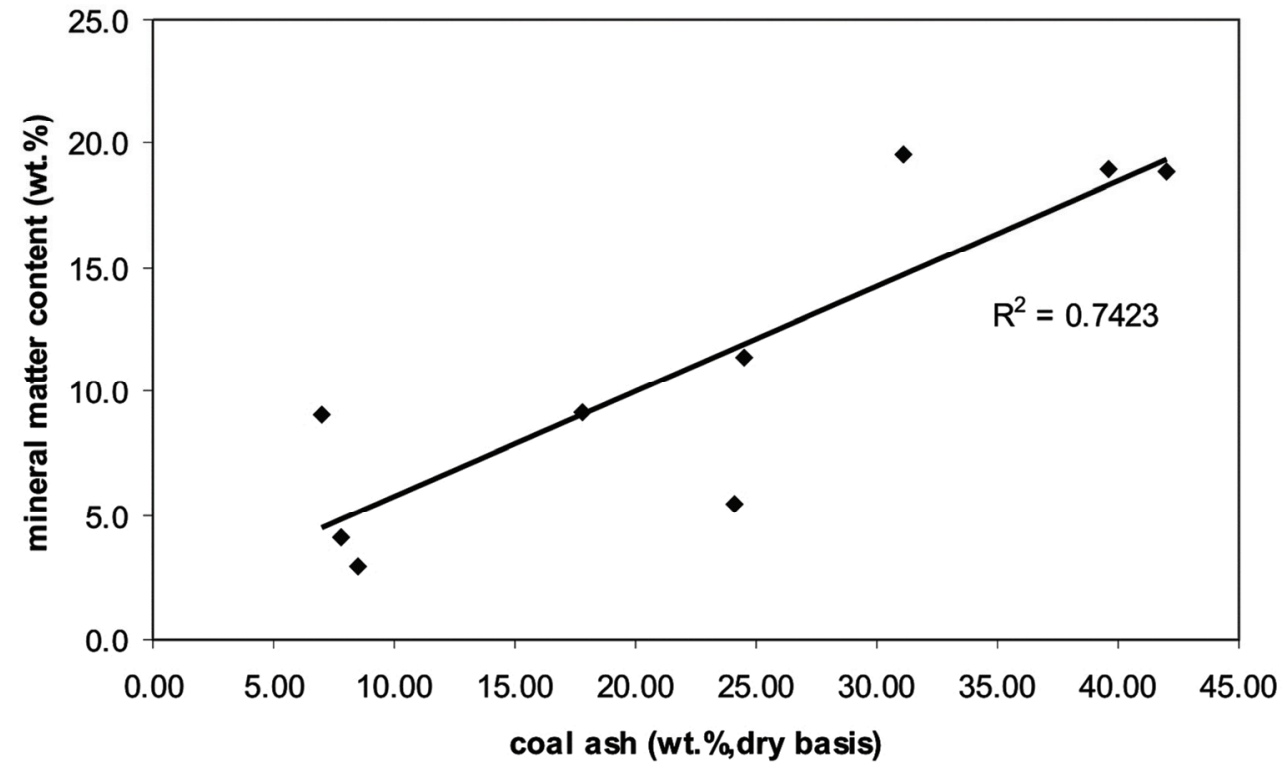

Fig. 2. The content of mineral matter vs. coal ash in the Stephanian coal samples analyzed from the Southern Cantabrain Zone (NW Spain).

The coal ash contents $\left(\mathrm{A}^{\mathrm{d}}\right)$ vary significantly from $7.0-42 \%$. Total sulphur contents $\left(\mathrm{St}^{\mathrm{d}}\right)$ range from $0.17-1.26 \%$ (Table 2). These values are broadly similar to those given by Colmenero et al. (2008). The coals examined are characterized by variable mineral-matter contents as evidenced by microscopic examinations and variations in the coal-ash contents (Tables 1,2). The relatively high ash yields in some samples $(4 \mathrm{~s}, 5 \mathrm{~s}, 11 \mathrm{~s}, 16 \mathrm{~s}$; Table 2) reflect abundant mineral clusters and dispersed mineral grains in the coal matrix (Fig. 2). The mineral matter primarily comprises clay minerals, carbonates (siderite, dolomite, calcite) and subordinate quartz as well as ore-minerals, mostly sulphides (Fig. 3). Sulphides mainly occur as single grains of dispersed pyrite (Fig. 3). Pyrite occurs as small, euhedral crystals or in framboidal concretionary forms commonly associated with collotelinite. This latter type of pyrite is usually interpreted to be of syngenetic origin formed in peat (Taylor et al. 1998). Other sulphides, e.g. galena, are rare (Fig. 3). Single grains of ilmenite, goethite, thenorite (?) and rutile (?) also occur. Carbonates are found in fractures and cell lumen. The clay minerals, though usually dispersed, may also occur in thin clay layers.

There is no correlation between coal rank and mineralogical content or between maceral contents and trace elements. It should be noted that a complete interpretation of the relations between trace elements and maceral groups, or between coal rank and changes in mineralogical content, would require a larger data base. 

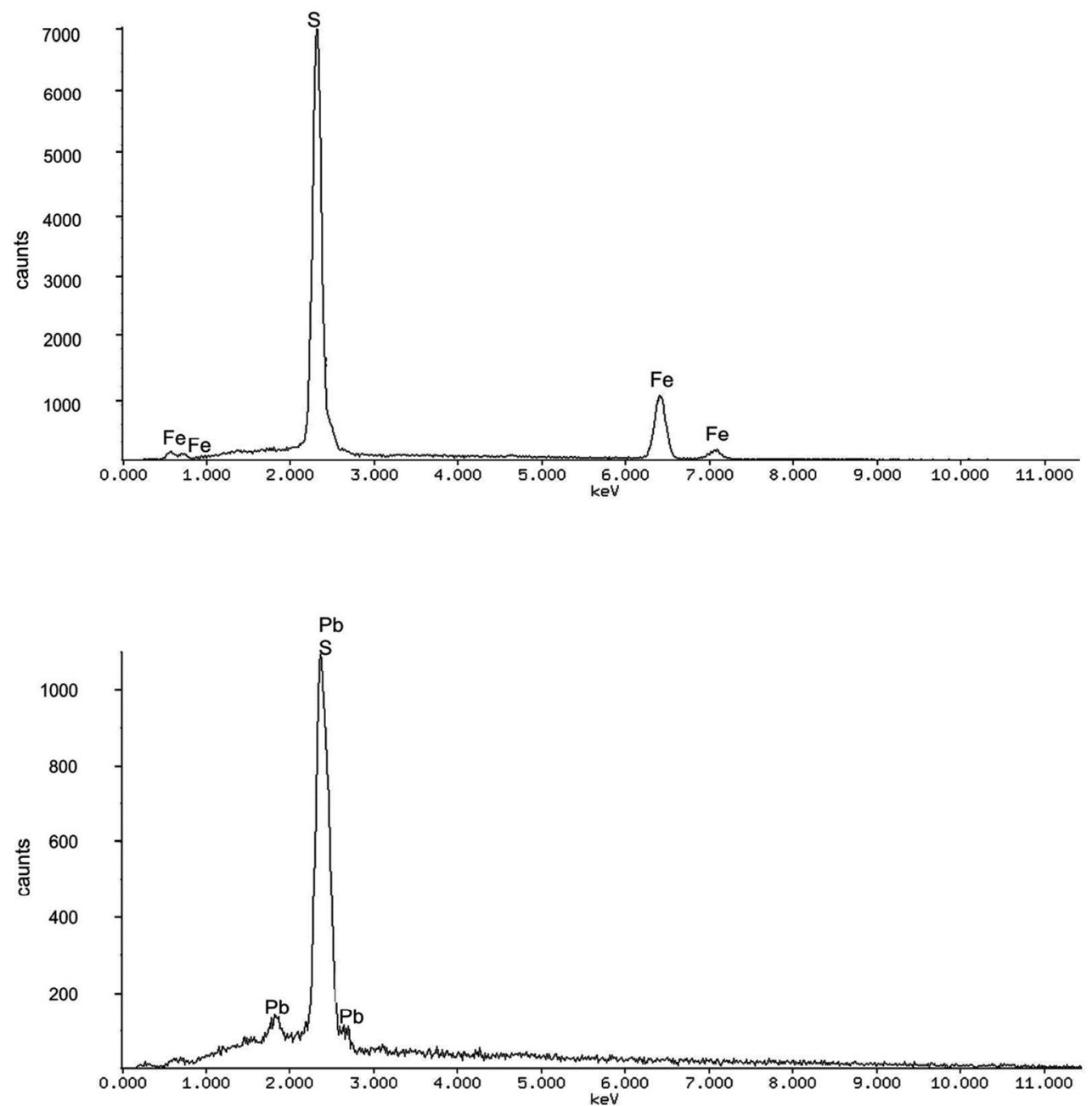

Fig. 3. The most common sulphide minerals contained in the coal samples analyzed from the Southern Cantabrain Zone (NW Spain). EDS spectra of galena (left) and pyrite (right).

The coals studied exhibit medium-high concentrations of the following elements (see for comparison Ketris, Yudovich 2009; Kabata-Pendias, Pendias 1999; Ronov et al. 1990; Table 3, this paper): REE (53-205), Ba (300-900), As (11-57), Zn (<50-150), Cr (10160), Rb (50-145), Co (5-26), Sc (2-24.6), Ce (17-99), Yb (1.3-4.5), Th (2.4-11.9), $\mathrm{U}(1.1-8.1), \mathrm{Br}(<1-14), \mathrm{Cs}(<2-9), \mathrm{Eu}(<0,3-1.5), \mathrm{Lu}(0.11-0.85)$ and $\mathrm{Sb}(0.8-4.8)$, relatively low concentrations of $\mathrm{Sm}(0.6-6.6)$ and $\mathrm{Ta}(<1-2)$ and a relatively high $\mathrm{Th} / \mathrm{U}$ value (1.31-2.29). Relatively high LREE/HREE values fall in the range 24-44 with an average of 30. In contrast, concentrations of $\mathrm{Au}, \mathrm{Ag}, \mathrm{Hg}, \mathrm{Ir}, \mathrm{Ni}, \mathrm{Se}, \mathrm{Sn}, \mathrm{Sr}$, and $\mathrm{W}$ are below detection limits for the INAA method applied. 
TABLE 3

Results of the INAA analysis of the coal and coal ash samples from the Stephanian coalfields of the Southern Cantabrian Zone.

\begin{tabular}{|c|c|c|c|c|c|c|c|c|c|c|}
\hline \multirow[t]{2}{*}{ Element } & \multirow{2}{*}{$\begin{array}{l}\text { Detection } \\
\text { Limit }\end{array}$} & \multicolumn{9}{|c|}{ Coal } \\
\hline & & $13 \mathrm{~S}$ & $7 \mathrm{~S}$ & $55 \mathrm{~S}$ & $75 \mathrm{~S}$ & $76 \mathrm{~S}$ & $81 \mathrm{~S}$ & $27 \mathrm{~S}$ & M18 & CM26 \\
\hline $\mathrm{Au}$ & 5 & $<5$ & $<5$ & $<5$ & $<5$ & $<5$ & $<5$ & $<5$ & $<5$ & $<5$ \\
\hline $\mathrm{Ag}$ & 5 & $<5$ & $<5$ & $<5$ & $<5$ & $<5$ & $<5$ & $<5$ & $<5$ & $<5$ \\
\hline As & 2 & 55 & 11 & 12 & 34 & 37 & 57 & 30 & 20 & 32 \\
\hline $\mathrm{Ba}$ & 100 & 800 & 900 & 300 & 300 & 400 & 500 & 600 & 500 & 600 \\
\hline $\mathrm{Br}$ & 1 & 5 & $<1$ & 12 & 14 & 8 & 8 & 7 & 7 & 6 \\
\hline $\mathrm{Ca}$ & 1 & $<1$ & $<1$ & $<1$ & $<1$ & 3 & $<1$ & $<1$ & $<1$ & $<1$ \\
\hline Co & 5 & 26 & 16 & 10 & 5 & 11 & 8 & 9 & 11 & 7 \\
\hline $\mathrm{Cr}$ & 10 & 160 & 130 & 30 & 10 & 80 & 60 & 60 & 20 & 70 \\
\hline Cs & 2 & 7 & 6 & 4 & $<2$ & 9 & 4 & 5 & $<2$ & 4 \\
\hline $\mathrm{Fe}$ & 0.02 & 2.13 & 2.43 & 1.44 & 3.64 & 2.56 & 1.33 & 1.87 & 0.65 & 1.04 \\
\hline Hf & 1 & 3 & 4 & 2 & $<1$ & 3 & 2 & 2 & $<1$ & 2 \\
\hline $\mathrm{Hg}$ & 1 & $<1$ & $<1$ & $<1$ & $<1$ & $<1$ & $<1$ & $<1$ & $<1$ & $<1$ \\
\hline $\mathrm{Ir}$ & 5 & $<5$ & $<5$ & $<5$ & $<5$ & $<5$ & $<5$ & $<5$ & $<5$ & $<5$ \\
\hline Mo & 5 & 9 & $<5$ & 6 & 9 & $<5$ & $<5$ & $<5$ & $<5$ & 5 \\
\hline $\mathrm{Na}$ & 0.05 & 0.08 & 0.08 & $<0.05$ & $<0.05$ & 0.09 & 0.08 & 0.09 & $<0.05$ & $<0.05$ \\
\hline $\mathrm{Ni}$ & 50 & $<50$ & $<50$ & $<50$ & $<50$ & $<50$ & $<50$ & $<50$ & $<50$ & $<50$ \\
\hline $\mathrm{Rb}$ & 30 & 99 & 90 & 50 & 55 & 70 & 50 & 70 & 95 & 145 \\
\hline $\mathrm{Sb}$ & 0.2 & 1.7 & 0.9 & 0.8 & 3.4 & 2.1 & 4.8 & 1.9 & 1.4 & 0.9 \\
\hline $\mathrm{Sc}$ & 0.1 & 24.6 & 15.1 & 4.8 & 2 & 10 & 6.8 & 9 & 2 & 8.8 \\
\hline $\mathrm{Se}$ & 5 & $<5$ & $<5$ & $<5$ & $<5$ & $<5$ & $<5$ & $<5$ & $<5$ & $<5$ \\
\hline $\mathrm{Sn}$ & 0.05 & $<0.05$ & $<0.05$ & $<0.05$ & $<0.05$ & $<0.05$ & $<0.05$ & $<0.05$ & $<0.05$ & $<0.05$ \\
\hline $\mathrm{Sr}$ & 0.1 & $<0.1$ & $<0.1$ & $<0.1$ & $<0.1$ & $<0.1$ & $<0.1$ & $<0.1$ & $<0.1$ & $<0.1$ \\
\hline $\mathrm{Ta}$ & 1 & $<1$ & 2 & $<1$ & $<1$ & $<1$ & $<1$ & $<1$ & $<1$ & $<1$ \\
\hline Th & 0.5 & 10.9 & 11.9 & 7.1 & 2.4 & 8.8 & 8 & 7.9 & 9.1 & 6 \\
\hline U & 0.5 & 6 & 8 & 3.1 & 1.1 & 5.8 & 6.1 & 4.9 & 6.2 & 3.9 \\
\hline $\mathrm{Th} / \mathrm{U}$ & & 1.82 & 1.49 & 2.29 & 2.18 & 1.52 & 1.31 & 1.61 & 1.47 & 1.54 \\
\hline W & 4 & $<4$ & $<4$ & $<4$ & $<4$ & $<4$ & $<4$ & $<4$ & $<4$ & $<4$ \\
\hline $\mathrm{Zn}$ & 50 & $<50$ & 150 & $<50$ & $<50$ & 110 & $<50$ & $<50$ & $<50$ & 60 \\
\hline $\mathrm{La}$ & 1 & 50 & 39 & 13 & 19 & 31 & 20 & 23 & 19 & 25 \\
\hline $\mathrm{Ce}$ & 3 & 97 & 62 & 34 & 99 & 71 & 46 & 58 & 17 & 50 \\
\hline $\mathrm{Nd}$ & 5 & 46 & 44 & 14 & 13 & 24 & 20 & 22 & 14 & 10 \\
\hline $\mathrm{Sm}$ & 0.1 & 6.6 & 5.8 & 1.4 & 0.6 & 3.6 & 2 & 2.3 & 0.9 & 2.2 \\
\hline LREE & & 199.6 & 150.8 & 62.4 & 131.6 & 129.6 & 88 & 105.3 & 50.9 & 87.2 \\
\hline $\mathrm{Eu}$ & 0.2 & 1.5 & 0.3 & 0.6 & 1 & 1.4 & 0.8 & 0.89 & 0.3 & 0.8 \\
\hline $\mathrm{Tb}$ & 0.5 & $<0.5$ & 0.5 & $<0.5$ & $<0.5$ & $<0.5$ & $<0.5$ & $<0.5$ & $<0.5$ & $<0.5$ \\
\hline $\mathrm{Yb}$ & 0.2 & 3 & 4.5 & 1.3 & 2 & 3 & 1.7 & 1.9 & 1.7 & 2.4 \\
\hline $\mathrm{Lu}$ & 0.05 & 0.85 & 0.6 & 0.19 & 0.4 & 0.48 & 0.27 & 0.38 & 0.11 & 0.34 \\
\hline HREE & & 5.4 & 5.9 & 2.1 & 3.4 & 4.9 & 2.8 & 3.2 & 2.1 & 3.5 \\
\hline $\mathrm{L} / \mathrm{H}$ & & 37.3 & 25.6 & 29.9 & 38.7 & 26.6 & 31.8 & 33.2 & 24.1 & 24.6 \\
\hline REE & & 204.95 & 156.70 & 64.49 & 135.00 & 134.48 & 90.77 & 108.47 & 53.01 & 90.74 \\
\hline
\end{tabular}




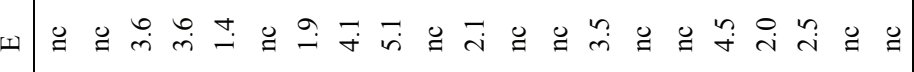

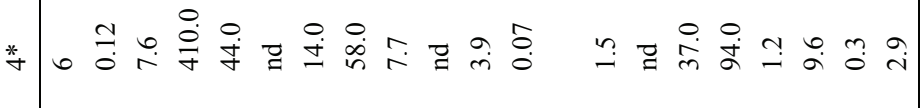

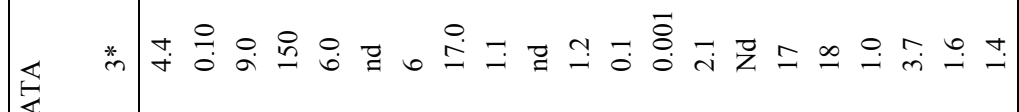

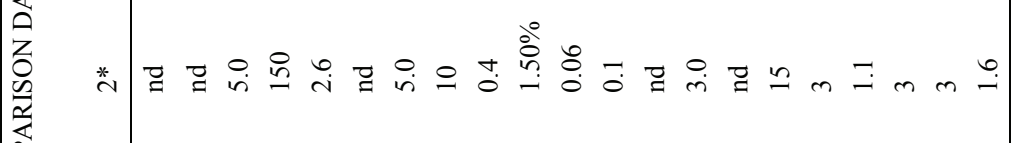

这

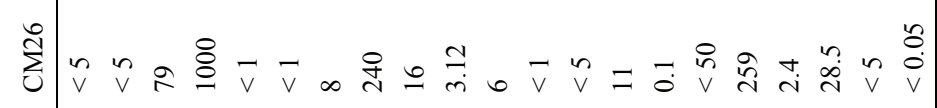

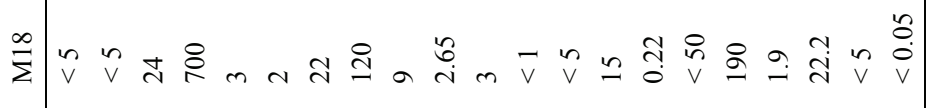

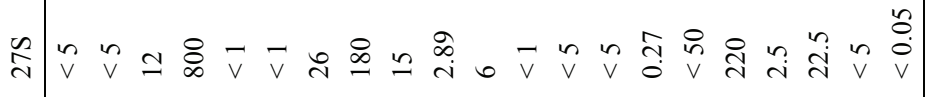

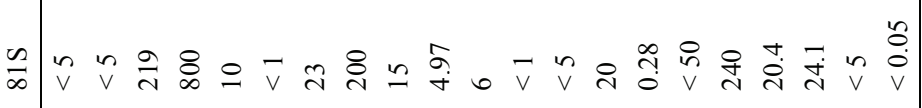

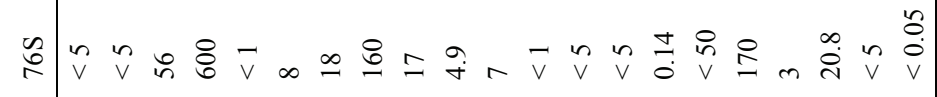

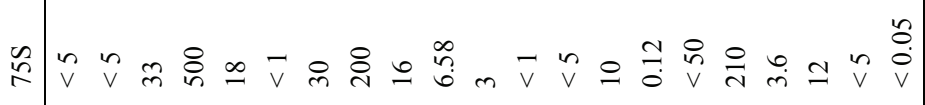

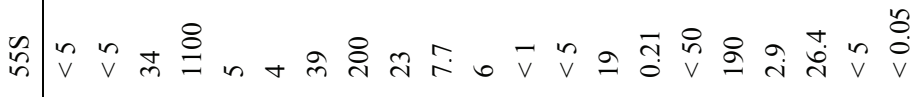

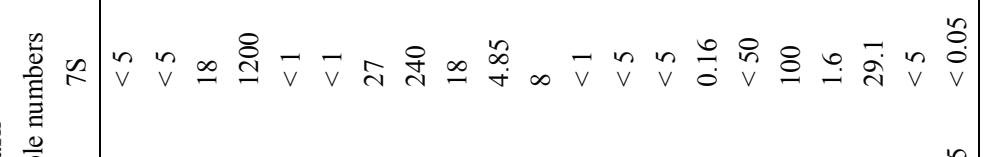

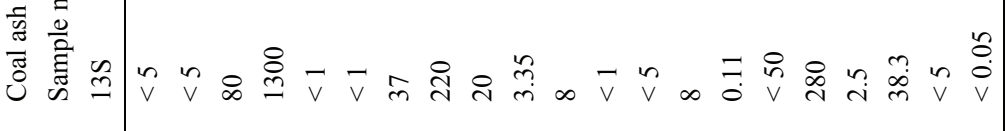

$\frac{\overrightarrow{0}}{\frac{\overrightarrow{0}}{\Psi}}$

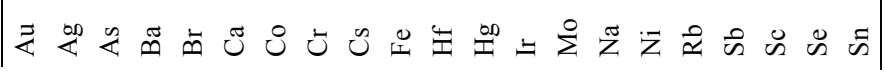




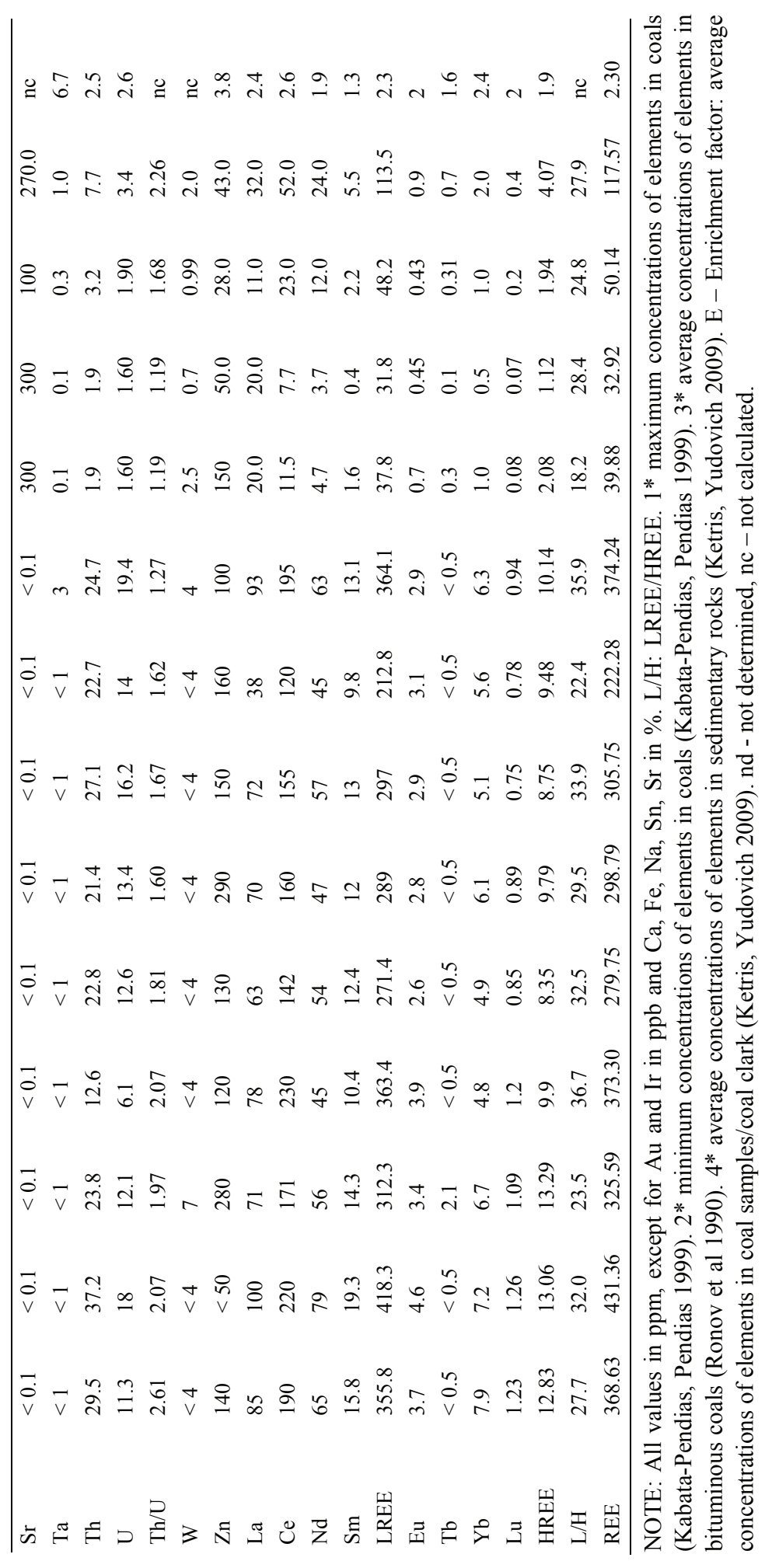


As the concentrations of elements are significantly higher in coal ash samples (Table 3), most of these elements are likely related to the mineral matter in the coals. The chemistry of these coals is comparable to that of the related tonsteins, at least in the Sabero coalfield (Botor 2005).

The coals are enriched in light rare earth elements (LREE) and exhibit a slight negative Eu anomaly and relatively flat heavy rare-earth element (HREE) patterns (Table 3). This suggests that the Stephanian coal mineral matter is derived primarily from clastic syngenetic source material (Valcovic 1983; Swaine 1995; Finkelman 1995). The REE show a correlation with contents of coal ash (Fig. 4).

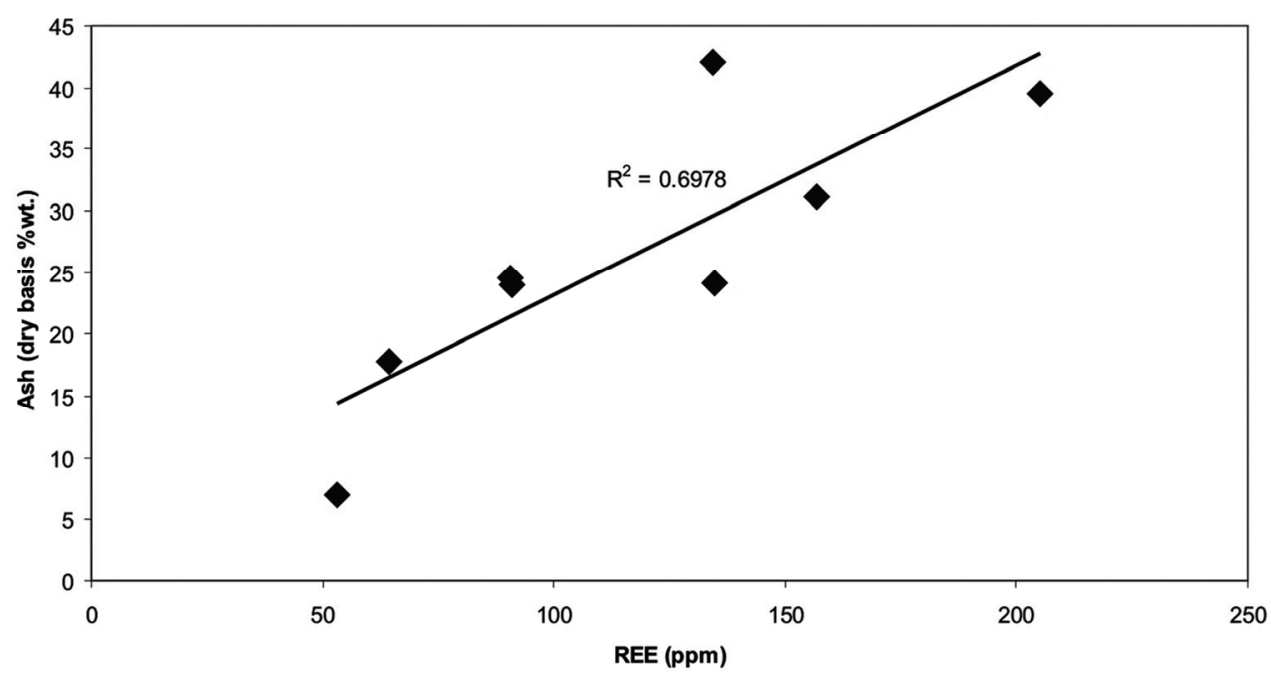

Fig. 4. Concentrations of REE vs. coal ash in the Stephanian coal samples from the Southern Cantabrain Zone (NW Spain).

Most of arsenic present is likely to be associated with the sulfide-rich fraction (pyrite, marcasite). Minor amounts of arsenic are also linked to the organic matter (Valcovic 1983). The arsenic concentrations in the SCZ coals range from 11-57 ppm (Table 3).

Enrichment factors (E) vary from 1.3-6.7 though most values are $<4$ (Table 3). Enrichment factor was calculated as the arithmetic average concentrations of elements in coal samples divided by coal clark (Ketris, Yudovich 2009). The highest value (6.7 for Ta) is based on a single sample. In the light of the well-known variation in concentrations of trace elements in coals worldwide (e.g. Finkelman 1995; Swaine 1995), the enrichment factors ranging from 1.3-4 are not particularly high. Thus, it is not really possible to infer any influence by hot fluids on coalification in this case. One of the initial aims of the present study was to determine if hot fluids circulating during the Carboniferous (e.g. Gassparini et al. 2006) could have affected the Stephanian coals in the SCZ. On a regional scale, a hydrothermal event is more or less contemporaneous with the increased heat flow related to the magmatism of the whole area (Bastida et al. 1999). Consequently, the metalbearing fluids would, a priori, have been associated with episodes of magmatism and 
remobilization of the crust occurring at the end of Carboniferous times (e.g. GómezFernández et al. 2000) which, therefore, could have influenced the Stephanian coals. However, hydrothermal circulation, although probable, has not been clearly confirmed by the presence of any diagnostic minerals or high concentrations of metal elements (e.g. Dai et al. 2004).

The coalfields are located in a highly-tectonised area and internal faults cannot be excluded (e.g. Knight et al. 2000). These could have as channels for fluid transport through these highly impermeable layers. More recently, Colmenero et al. (2008) have suggested that high thermal fluxes associated with magmatic events seem to have provided the necessary heat to accelerate the evolution of coal seams in the Stephanian coalfields to anthracite rank in the Cantabrian Mountains. This magmatism could also have promoted hydrothermal fluid migration, especially in the areas of deep-seated faults along the SaberoGordon line (Gómez-Fernández et al. 2000).

In fact, the lack of any regular regional pattern in coal rank may reflect magmatic intrusion below and hydrothermal-fluid migration and/or tectonics (Botor 2009). This is the reason why it is difficult, at this stage of the research, to assess which of these factors was the major influence on coal rank. Coalification occurring in the Early Permian may have been associated with high heat flow due to magmatic- and hydrothermal activity in some parts of the SCZ and due to a high rate of basin subsidence in the pull-apart basin (Botor 2009).

\section{Conclusions}

The coals examined are characterized by relatively variable mineral-matter and coal-ash contents. The mineral matter comprises primarily clay minerals and carbonates as well as sulphides and quartz. The coals exhibit moderate-high concentrations (enrichment factors $>2.5$ ) of REE, As, Ba, Cr, Cs, Mo, Rb, Sc, La, Ce, Yb, Th, U, and Zn, and a relatively high LREE/HREE. Geochemical investigations of the coals in the SCZ are to be continued. The results will be used to determine the balance of trace-metal concentrations in the coal and in its treatment products.

Acknowledgements. This study was partially financed by Polish Ministry of Science and Higher Education, grant 2307/T02/2007/32, and AGH-UST grant 10.10.140.153, 10.10.140.781. I would like to thank: Dr. J.A. Knight (Derby, UK) for my introduction to the regional geology of the Sabero basin, Prof. C. Brime (University of Oviedo) for valuable remarks and detailed maps of the Southern Cantabrian Zone, Dr. P. Dzierżanowski (Warsaw University) for assistance with EDS/WDS analyses, Dr hab. A. Pieczka (AGH-UST) for valuable discussion on trace elements and mineral matter in coal and Dr. J. Misiak and Prof. M. Wagner (AGH-UST) for fruitful discussion on coal petrology.

\section{References}

Aller, J., Valin, M.L., Garcia-Lopez, S., Brime, C., \& Bastida, F. (2005). Superposition of tectono-thermal episodes in the southern Cantabrian Zone (foreland thrust and fold belt of the Iberian Variscides, NW Spain. Bulletin de la Societe Geologique de France, 176(6), 487-497. 
Bastida, A. F, Brime, C., Garcia-Lopez, S., \& Sarmiento, G.N. (1999). Tectono-thermal evolution in a region with thin-skinned tectonics; the western nappes in the Cantabrian Zone (NW Spain). International Journal of Earth Sciences, 88(1), 38-48.

Botor, D. (2005). Geochemistry of the Upper Carboniferous tonsteins from the Sabero coalfield (NW Spain). Zeszyty Naukowe Politechniki Śląskiej, Seria Górnictwo 268, 19-30.

Botor, D. (2009). Paleogeothermal evolution of the Sabero Coalfield. Report of grant the Polish Ministry of Science and Higher Education, no. 2307/T02/2007/32 (in Polish).

Brime, C., Garcia-Lopez, S., Bastida, F., Valin, M. L., Sanz-Lopez, J., \& Aller, J. (2001). Transition from diagenesis to metamorphism near the front of the Variscan regional metamorphism (Cantabrian Zone, NW Spain). Journal of Geology, 109(3), 363-379.

Cohen, A.D., Spackman, W., \& Dolsen, P. (1984). Occurrence of trace elements in peat-forming environments of southern Florida. International Journal of Coal Geology, 4(1), 73-96.

Colmenero, J.R., \& Prado, J.G. (1993). Coal basins in the Cantabrian Mountains, NW Spain. International Journal of Coal Geology, 23(1-4), 215-229.

Colmenero, J.R., Suárez-Ruiz, I., Fernández-Suárez, J., Barba, P., \& Llorens, T. (2008). Genesis and rank coal basins in the Cantabrian Mountains, NW Spain. International Journal of Coal Geology 76(3), 187-204.

Dai, S., Li, D., Ren, D., Tang, Y., Shao, L., \& Song, H. (2004). Geochemistry of the Late Permian No. 30 coal seam, Zhijin Coalfield of Southwest China: influence of a siliceous low-temperature hydrothermal fluid. Applied Geochemistry, 19(8), 1315-1330.

Finkelman, R.B. (1995). Modes of occurrence of environmentally-sensitive trace elements in coal. In D. J. Swaine \& F. Goodarzi (Eds.), Environmental Aspects of Trace Elements of Coal (pp. 24-50). Dordrecht: Kluwer Academic Publishers.

Frings, U., Lutz, R., De Wall, H., \& Warr, L.N. (2004). Coalification history of the Cinera-Matallana pull-apart basin (NW Spain). International Journal of Earth Sciences, 93(1), 92-106.

Gassparini, M., Bechstädt T., \& Boni M. (2006). Massive hydrothermal dolomites in the southwestern Cantabrian Zone (Spain) and their relation to the Late Variscan evolution. Marine and Petroleum Geology, 23(5), 543568.

Gómez-Fernández, F., Both, R.A., Mangas, J. \& Arribas, A. (2000). Metallogenensis of Zn-Pb Carbonate-Hosted mineralisation in the southeastern region of the Picos de Europa (Central Northern Spain) Province: geologic, fluid inclusion and stable isotope studies. Economic Geology, 95(1), 19-40.

Heward, A.P. (1978). Alluvial fan and lacustrine sediments from the Stephanian A and B (La Magdalena, CineraMatallana and Sabero) coalfields, northern Spain. Sedimentology, 25(4), 451-488.

Heward, A.P., \& Reading, H.G. (1980). Deposits associated with a Hercynian to Late Hercynian continental strike-slip system, Cantabrian Mountains, Northern Spain. In: P. F. Ballance \& H. G. Reading (Eds.), Sedimentation in Oblique-Slip Mobile Zones (pp. 105-125). Special Publication of the International Association of Sedimentologists, 4. Wiley.

International Organization for Standardization. (1994). Methods for the Petrographic Analysis of Bituminous Coal and Anthracite - Part 5: Methods Determining Microscopically the Reflectance of Vitrinite. ISO 7404-5 1994, Geneva, Switzerland.

Kabata-Pendias, A., \& Pendias, H. (1999). Biogeochemistry of Trace Elements. Warsaw: Wydawnictwo Naukowe PWN.

Ketris, M.P., \& Yudovich, Y.E. (2009). Estimations of clarkes for carbonaceous bioliths: world averages for trace element contents in black shales and coals. International Journal of Coal Geology, 78(2), 135-148.

Knight, J.A. (1983). The Stratigraphy of the Stephanian Rocks of the Sabero Coalfield, Léon (NW. Spain) and an investigation of the fossil flora. Part I: The stratigraphy and general geology of the Sabero Coalfield Paleontographica, Abt. B, 187(1-3), 1-88.

Knight, J.A., Burger, K, \& Bieg, G. (2000). The pyroclastic tonsteins of the Sabero Coalfield, north-western Spain, and their relationship to the stratigraphy and structural geology. International Journal of Coal Geology, 44(3-4), 187-226.

Marcos, A., \& Pulgar, J. A. (1982). An approach to the tectonostratigraphic evolution in the Cantabrian Foreland thrust and fold belt, Hercynian Cordillera of NW Spain. Neues Jahrbuch Geologie und Paläontologie, 163(2), 256-260.

Pérez-Estaún, A., Bastida, F., Alonso, J.L., Marquinez, J., Aller, J., Alvarez-Marrón, J., Marcos, A., \& Pulgar, J. A. (1988). A thin-skinned tectonics model for an arcuate fold and thrust belt: the Cantabrian Zone (Variscan Ibero-Armorican Arc). Tectonics, 7(3), 517-537. 
Polski Komitet Normalizacyjny (National Standards Authority in Poland). (2001). Paliwa stałe - Oznaczanie zawartości siarki całkowitej i popiołowej automatycznymi analizatorami. PN-G-04584, ISBN 83-236-6958-9, 1-5. Warszawa.

Polski Komitet Normalizacyjny (National Standards Authority in Poland). (2002). Paliwa stałe - Oznaczanie popiołu. PN-ISO 1171, ISBN 83-236-8847-8, 7. Warszawa.

Polski Komitet Normalizacyjny (National Standards Authority in Poland). (2007). Klasyfikacja węgla. PN-ISO 11760-2007. ISBN 978-83-251-2358-1, 16.

Querol, X., Juan, R., Lopez-Soler A., Fernandez-Turiel J.L., \& Ruiz C. R. (1996). Mobility of trace elements from coal and combustion wastes. Fuel, 75(7), 821-838.

Ronov, A.B., Yaroshevsky, A.A., \& Migdisov, A.A. (1990). Chemical Composition of the Earth's Crust and Geochemical Balance of Main Elements. Moscow: Nauka, Science Pub. House. (in Russian).

Swaine, D.J. (1995). The contents and some related aspects of trace elements in coals. In D.J. Swaine \& F. Goodarzi (Eds.), Environmental Aspects of Trace Elements in Coal (pp. 5-23). Dordrecht: Kluwer Academic Publishers.

Taylor, G.H., Teichmüller, M., Davis, A., Diessel, C.F.K., Littke, R., \& Robert, P. (1998). Organic Petrology. Berlin-Stuttgart: Gebrüder Borntraeger.

Valcovic, V. (1983). Trace Elements in Coal. Boca Raton, Florida: CRC Press Inc. 